\title{
PENERAPAN STRATEGI THE FIRING LINE DALAM MENINGKATKAN AKTIVITAS BELAJAR MATA PELAJARAN IPS SISWA KELAS VII.2 SMPN 21 PEKANBARU
}

\author{
Yusmiarti \\ SMP Negeri 21 Pekanbaru \\ e-mail: yusmiarti21@yahoo.com
}

\begin{abstract}
This study aims to determine the application of the firing line strategy in improving the learning activities of social studies subjects IPS class VII.2 SMPN 21 Pekanbaru. The subjects of this study are all students of class VII.2 SMPN 21 Pekanbaru which amounted to 42 people, the academic year 2016-2017. The form of research is classroom action research. The instrument of this research consisted of performance instrument and data collection instrument in the form of observation sheet of teacher activity and student activity. Based on the results of the study can be concluded that through the firing line strategy in the learning process of social studies learning activities of students of class VII.2 SMPN 21 Pekanbaru known the average student activity becomes better when compared with before the implementation of learning strategy. Prior to the implementation of the firing line strategy, students' activeness earned an average percentage of $53.6 \%$ of active students. However, after the implementation of the strategy, students' activity in the first cycle increased to $65.3 \%$. In the second cycle, students' activity reached an average of $88.2 \%$.
\end{abstract}

Keywords - The firing line strategy, learning activities, learning strategy.

\begin{abstract}
Abstrak
Penelitian ini bertujuan untuk mengetahui penerapan strategi the firing line dalam meningkatkan aktivitas belajar mata pelajaran IPS siswa kelas VII.2 SMPN 21 Pekanbaru. Subjek penelitian ini adalah semua siswa kelas VII.2 SMPN 21 Pekanbaru yang berjumlah 42 orang, tahun pelajaran 2016-2017. Bentuk penelitian adalah penelitian tindakan kelas. Instrumen penelitian ini terdiri dari instrumen unjuk kerja dan instrumen pengumpulan data berupa lembar observasi aktivitas guru dan aktivitas siswa. Berdasarkan hasil penelitian dapat disimpulkan bahwa rnelalui strategi the firing line dalam proses pembelajaran IPS aktivitas belajar siswa kelas VII.2 SMPN 21 Pekanbaru diketahui rata-rata keaktifan siswa menjadi lebih baik jika dibandingkan dengan sebelum diterapkannya strategi pembelajaran tersebut. Sebelum diterapkannya strategi the firing line, keaktifan siswa memperoleh persentase rata-rata sebesar 53,6\% siswa yang aktif. Namun setelah diterapkannya strategi tersebut, keaktifan siswa pada siklus pertama meningkat menjadi 65,3\%. Pada siklus kedua, keaktifan siswa tercapai pada ratarata $88,2 \%$.
\end{abstract}

Kata kunci-Strategi the firing line, aktivitas belajar, strategi pembelajaran.

\section{PENDAHULUAN}

Masnur Musllich (2007:20) mengemukakan bahwa KBK (Kurikulum Berbasis Kompetensi) dan KTSP (Kurikulum Tingkat Satuan Pendidikan) dikembangkan berdasarkan beberapa karakteristik atau ciri utama. Misalnya berfokus pada tiga ciri utama, yaitu (1) berpusat pada siswa, (2) memberikan mata pelajaran dan pengalaman belajar yang relevan dan kontekstual, dan (3) mengembangkan mental yang kaya dan kuat pada siswa.

Siswa atau anak didik adalah salah satu komponen manusiawi yang menempati posisi sentral dalam proses belajar mengajar. Di dalam proses belajar mengajar, siswa sebagai pihak yang ingin meraih cita-cita, memiliki tujuan dan kemudian ingin mencapainya secara optimal. Siswa atau anak didik itu akan menjadi faktor penentu, sehingga menuntut dan dapat mempengaruhi segala sesuatu 
yang diperlukan untuk mencapai tujuan belajarnya. Jadi dalam proses belajar mengajar yang diperhatikan pertama kali adalah siswa atau anak didik, bagaimana keadaan dan kemampuannya, baru setelah itu menentukan komponen-komponen yang lain. Apa bahan yang diperlukan, bagaimana cara yang tepat untuk bertindak, alat dan fasilitas apa yang cocok dan mendukung, semua itu harus disesuaikan dengan keadaan/karakteristik siswa. Itulah sebabnya siswa atau anak didik adalah merupakan subjek belajar.

Ilmu Pengetahuan Sosial (IPS) merupakan salah satu mata pelajaran yang diberikan dimulai dari SD/MI/SDSLB sampai SMP /MTs/SMPLB. IPS mengkaji seperangkat peristiwa, fakta, konsep, dan generalisasi yang berkaitan dengan isu sosial. Pada jenjang SD/MI mata pelajaran IPS memuat materi geografi, sejarah, sosiologi, dan ekonomi. Melalui mata pelajaran IPS, peserta didik diarahkan untuk dapat menjadi warga negara Indonsia yang Demokratis, dan bertanggung jawab, serta warga dunia yang cinta damai. (Depdiknas, 2003:74)

Berdasarkan penjelasan tersebut jelaslah bahwa mata pelajaran pendidikan Ilmu Pengetahuan Sosial (IPS) merupakan pendidikan yang bertujuan membentuk peserta didik menjadi manusia yang bertanggung jawab, cerdas sebagaimana tertuang dalam Undang-Undang No 20 tahun 2003 tentang Sisdiknas pasal 6 menyebutkan bahwa :

Setiap warga negara yang berusia tujuh sampai dengan lima belas tahun wajib mengikuti pendidikan dasar, bertanggung jawab terhadap kelangsungan penyelenggaraan pendidikan. (Dasar, fungsi dan tujuan, pasal 3) mengatakan bahwa Pendidikan Nasional berfungsi mengembangkan kemampuan dan membentuk watak serta peradaban bangsa bermartabat dalam rangka mencerdaskan kehidupan bangsa bertujuan untuk berkembangnya potensi peserta didik agar menjadi manusia yang beriman dan bertaqwa kepada Tuhan Yang Maha Esa, berakhlak mulia, sehat, berilmu, cakap, kreatif, mandiri dan menjadi warga negara yang demokratis serta bertanggung jawab.

Salah satu faktor eksternal yang mempengaruhi aktivitas belajar siswa adalah cara mengajar/metode guru dalam menyampaikan materi pelajaran kepada siswa. Berdasarkan kenyataan menunjukkan bahwa cara mengajar guru di kelas cenderung hanya menggunakan caracara klasik seperti ceramah ataupun tanya jawab, sehingga siswa cenderung menjadi pasif dan kurang semangat belajarnya.

Dewasa ini para ahli, terutama yang berkecimpung dalam bidang pendidikan banyak menaruh perhatian terhadap upaya mengaktifkan siswa belajar. Pelaksanaan pengajaran yang menjadikan siswa pasif banyak memperoleh kritik.

Untuk itu kemampuan guru sangat dituntut dalam mengelolah kelas agar suasana belajar siswa selalu aktif dan produktif melalui strategi dan metode mengajar yang direncanakan. Mengajar itu sendiri juga merupakan serangkaian peristiwa yang dirancang oleh guru dalam memberi dorongan kepada siswa belajar baik yang bersifat individual maupun klasikal. Rangkaian peristiwa dalam mengajar, sebagai pendorong siswa belajar diterima oleh siswa secara individual pula. Artinya setiap individu siswa memperolah pengaruh dari luar dalam proses belajar dengan kadar yang berbeda-beda. Sesuai dangan kemampuan potensial masing-masing. Oleh karena itu aktivitas belajar pun akan berbeda-beda pula.

Berdasarkan hasil survey dan wawancara dengan guru IPS di SMPN 21 Pekanbaru ditemui gejala-gejala atau fenomena khususnya pada pelajaran IPS sebagai berikut:

1. Sebagian siswa ada yang mengantuk ketika guru menyampaikan materi pelajaran yang sedang dipelajari.

2. Dalam proses pembelajaran sebagian besar siswa kurang aktif, hal ini terlihat dari aktivitas siswa yang kurang memperhatikan guru yang sedang menyampaikan materi pelajaran.

3. Dalam proses pembelajaran siswa cederung lebih banyak diam, hanya menerima materi yang disampaikan oleh guru selain itu siswa jarang mengajukan pertanyaan ataupun memberikan tanggapan setelah guru menjelaskan materi pelajaran.

Dari fenomena-fenomena atau gejala-gejala tersebut di atas, terlihat bahwa aktivitas belajar siswa belum optimal, khususnya pada pelajaran IPS. Hal ini berkemungkinan dipengaruhi oleh cara mengajar guru yang kurang menarik perhatian siswa. Kondisi ini senada dengan pernyataan Nasution dalam Djamarah memandang belajar itu bukanlah suatu aktivitas yang berdiri sendiri. Mereka berkesimpulan ada unsur-unsur lain yang ikut terlibat langsung di dalamnya, yaitu masukan mentah (raw input) merupakan bahan pengalaman belajar tertentu dalam proses belajar 
mengajar (learning teaching process) dengan harapan dapat berubah menjadi keluaran (out put) dengan kualifikasi tertentu. Di dalam proses belajar itu ikut berpengaruh sejumlah faktor lingkungan,yang merupakan masukan dari lingkungan (invironmental input) dan sejumlah faktor, instrumental (instrumental input) yang dengan sengaja dirancang dan dimanipulasikan guna menunjang tercapainya keluaran yang dikehendaki. (Djamarah, 2002:141)

Hal senada dikemukakan oleh Muhibbin Syah (2006:132) secara global, faktor-faktor yang mempengaruhi belajar seseorang dapat dibedakan menjadi tiga macam yaitu faktor internal (faktor dari dalam diri siswa) yakni keadan/kondisi jasmani dan rohani siswa, faktor eksternal (faktor dari luar siswa)yakni kondisi lingkungan di sekitar siswa dan faktor pendekatan belajar (approach to learning) yakni jenis upaya belajar siswa yang meliputi Strategi dan strategi yang digunakan untuk melakukan kegiatan pembelajaran materi-materi pelajaran.

Salah satu usaha guru yang dapat dilakukan adalah menerapkan strategi pembelajaran yang bertujuan mengaktifkan siswa yaitu supaya siswa mau bertanya tentang materi yang sedang dipelajari terlebih dahulu kepada teman sekelompoknya, bersemangat untuk mengerjakan latihan serta mempunyai rasa tanggung jawab dengan tugas dan kelompoknya. Maka perlu digunakan pembelajaran kooperatif. Saat ini strategi pembelajaran kooperatif semakin berkembang. Salah satu satu pembelajaran kooperatif adalah dengan strategi The Firing Line.

Berdasarkan permasalah di atas penulis tertarik untuk melakukan suatu tindakan perbaikan melalui penelitian dengan judul: Penerapan Strategi The Firing Line Dalam Meningkatkan Aktivitas Belajar Mata Pelajaran IPS Siswa Kelas VII.2 SMPN 21 Pekanbaru.

\section{METODE}

Penelitian dilaksanakan di SMPN 21 Pekanbaru pada Kelas VII.2 pada tahun 2016. Penelitian ini telah dilaksanakan pada Agustus sampai September 2016. Penelitian ini dilakukan dalam 2 siklus. Subjek dalam penelitian ini adalah siswa VII.2 SMPN 21 Pekanbaru tahun pelajaran 2016-2017 dengan jumlah murid sebanyak 42 orang. Jenis penelitian ini adalah Penelitian Tindakan Kelas (PTK). Penelitian Tindakan Kelas (PTK) merupakan salah satu langkah dalam mengembangkan keterampilan dan meningkatkan kinerja guru agar keberhasilan proses belajar mengajar dalam pencapaian hasil belajar dapat di peroleh semaksimal mungkin.

\section{HASIL DAN PEMBAHASAN}

\section{Hasil Penelitian}

\section{a. Sebelum Siklus}

Setelah menganalisis hasil observasi awal aktivitas belajar siswa, yang telah diketahui bahwa aktivitas belajar siswa secara klasikal dalam pelajaran IPS diperoleh jumlah skor 788 berada pada kategori rendah, atau dengan rata-rata 53,6 \%, dengan kategori kurang tinggi. Agar lebih jelas dapat dilihat pada, tabel sebagai berkut: 
Tabel 1. Aktivitas Belajar Sebelum Tindakan

\begin{tabular}{|c|c|c|c|c|c|c|c|c|c|c|}
\hline \multirow[b]{2}{*}{ NO } & \multirow[b]{2}{*}{ Kode Siswa } & \multicolumn{7}{|c|}{ Indikator } & \multirow[b]{2}{*}{ Skor } & \multirow[b]{2}{*}{ Kategori } \\
\hline & & 1 & 2 & 3 & 4 & 5 & 6 & 7 & & \\
\hline 1 & Adelia & 3 & 3 & 2 & 2 & 2 & 2 & 2 & 16 & Rendah \\
\hline 2 & Adinda & 2 & 2 & 2 & 2 & 2 & 2 & 2 & 14 & Rendah \\
\hline 3 & Adinda Salwa & 2 & 2 & 3 & 2 & 2 & 2 & 3 & 16 & Rendah \\
\hline 4 & Amei & 2 & 2 & 2 & 3 & 2 & 3 & 3 & 17 & Rendah \\
\hline 5 & Anisa & 3 & 3 & 3 & 3 & 3 & 4 & 3 & 22 & Tinggi \\
\hline 6 & Charina Ramadhani & 3 & 3 & 2 & 3 & 2 & 3 & 3 & 19 & Rendah \\
\hline 7 & Cindi Amalia & 2 & 3 & 3 & 3 & 3 & 3 & 3 & 20 & Rendah \\
\hline 8 & Fajri & 3 & 3 & 3 & 2 & 2 & 3 & 3 & 19 & Rendah \\
\hline 9 & Farhan Hakim & 2 & 3 & 2 & 3 & 2 & 3 & 3 & 18 & Rendah \\
\hline 10 & Habib Rizki & 3 & 2 & 2 & 3 & 2 & 3 & 3 & 18 & Rendah \\
\hline 11 & Keysa Labora & 3 & 2 & 3 & 2 & 2 & 2 & 3 & 17 & Rendah \\
\hline 12 & Kurnia Adil & 3 & 3 & 2 & 3 & 3 & 3 & 3 & 20 & Rendah \\
\hline 13 & Michel & 2 & 3 & 3 & 3 & 3 & 3 & 3 & 20 & Rendah \\
\hline 14 & Miftahul Riski & 2 & 2 & 2 & 3 & 2 & 3 & 3 & 17 & Rendah \\
\hline 15 & Muhammad Azarin & 3 & 3 & 3 & 3 & 3 & 4 & 3 & 22 & Tinggi \\
\hline 16 & Muhammad Birna & 3 & 3 & 2 & 3 & 2 & 3 & 3 & 19 & Rendah \\
\hline 17 & Muhammad Pandra & 2 & 3 & 3 & 3 & 3 & 3 & 3 & 20 & Rendah \\
\hline 18 & Novita Dela & 3 & 3 & 3 & 2 & 2 & 3 & 3 & 19 & Rendah \\
\hline 19 & Olga Diva & 2 & 3 & 2 & 3 & 2 & 3 & 3 & 18 & Rendah \\
\hline 20 & Omar Harist & 3 & 2 & 2 & 3 & 2 & 3 & 3 & 18 & Rendah \\
\hline 21 & Pahrianto & 3 & 2 & 3 & 2 & 2 & 2 & 3 & 17 & Rendah \\
\hline 22 & Pinkan & 3 & 3 & 2 & 3 & 2 & 3 & 3 & 19 & Rendah \\
\hline 23 & Putri & 2 & 3 & 3 & 3 & 3 & 3 & 3 & 20 & Rendah \\
\hline 24 & Rafli Hazizi & 3 & 3 & 3 & 2 & 2 & 3 & 3 & 19 & Rendah \\
\hline 25 & Rahmat & 2 & 3 & 2 & 3 & 2 & 3 & 3 & 18 & Rendah \\
\hline 26 & Raisha & 3 & 2 & 2 & 3 & 2 & 3 & 3 & 18 & Rendah \\
\hline 27 & Reyhan Iskandar & 3 & 2 & 3 & 2 & 2 & 2 & 3 & 17 & Rendah \\
\hline 28 & Ria Melati & 3 & 3 & 2 & 3 & 3 & 3 & 3 & 20 & Rendah \\
\hline 29 & Rika Putri & 2 & 3 & 3 & 3 & 3 & 3 & 3 & 20 & Rendah \\
\hline 30 & Salsabila Montia & 3 & 3 & 3 & 3 & 3 & 3 & 3 & 21 & Tinggi \\
\hline 31 & Salsabila Trisuci & 3 & 2 & 3 & 2 & 2 & 2 & 3 & 17 & Rendah \\
\hline 32 & Salsanabilah & 3 & 3 & 2 & 3 & 2 & 3 & 3 & 19 & Rendah \\
\hline 33 & Salwa Febrianty & 2 & 3 & 3 & 3 & 3 & 3 & 3 & 20 & Rendah \\
\hline 34 & Satria Eka & 3 & 3 & 3 & 2 & 2 & 3 & 3 & 19 & Rendah \\
\hline 35 & Syifa Salsabila & 2 & 3 & 2 & 3 & 2 & 3 & 3 & 18 & Rendah \\
\hline 36 & Viola & 3 & 2 & 2 & 3 & 2 & 3 & 3 & 18 & Rendah \\
\hline 37 & Vionita & 3 & 2 & 3 & 2 & 2 & 2 & 3 & 17 & Rendah \\
\hline 38 & Wincem Sukma & 3 & 3 & 2 & 3 & 3 & 3 & 3 & 20 & Rendah \\
\hline 39 & Wisnaini & 2 & 3 & 3 & 3 & 3 & 3 & 3 & 20 & Rendah \\
\hline 40 & Yudhika Muthia & 3 & 2 & 3 & 3 & 3 & 3 & 3 & 20 & Rendah \\
\hline 41 & Yulia Fitri & 3 & 3 & 3 & 3 & 3 & 3 & 3 & 21 & Tinggi \\
\hline 42 & Zidan & 3 & 3 & 3 & 3 & 3 & 3 & 3 & 21 & Tinggi \\
\hline & Jumlah & 111 & 112 & 107 & 114 & 100 & 120 & 124 & 788 & Sangat Tinggi \\
\hline & rata-rata $(\%)$ & 52.9 & 53.3 & 51.0 & 54.3 & 47.6 & 57.1 & 59.0 & 53.6 & Kurang tinggi \\
\hline
\end{tabular}

Diketahui bahwa aktivitas belajar siswa mata pelajaran IPS secara klasikal masih tergolong rendah dengan perolehan skor 788, karena 788 berada pada interval tergolong rendah dengan nilai rata-rata sebesar $53,6 \%$. Oleh karna itu, peneliti melakukan langkah perbaikan untuk mengatasi masalah rendahnya aktivitas belajar siswa mata pelajaran IPS dengan strategi The Firing Line.

\section{b. Siklus I}

Siklus 1 pertemuan pertama aktivitas belajar dapat disimpulkan bahwa aktivitas belajar siswa pada siklus pertama secara klasikal diperoleh jumlah skor 808 berada pada interval dengan kategori rendah. Kemudian rata-rata klasikal aktivitas belajar siswa adalah $55 \%$ tergolong kurang tinggi. Sedangkan pertemuan kedua disimpulkan bahwa aktivitas belajar siswa pada siklus pertama secara klasikal diperoleh jumlah skor 905 berada pada interval dengan kategori cukup tinggi. Kemudian rata-rata klasikal aktivitas belajar siswa adalah 61,6\% tergolong cukup tinggi. Dan pertemuan ketiga dapat disimpulkan bahwa aktivitas belajar siswa pada siklus pertama secara klasikal diperoleh jumlah skor 960 berada pada interval dengan kategori tinggi. Kemudian rata-rata klasikal aktivitas belajar siswa adalah $65,3 \%$ tergolong cukup tinggi.

Refleksi siklus pertama diperoleh berdasarkan hasil analisis data untuk tiap-tiap langkah pelaksanaan tindakan yang akan dideskripsikan peneliti pada tahap ini. Selanjutnya didiskusikan dengan observer, yang berperan sebagai observer yaitu teman sejawat. Adapun refleksi siklus pertama adalah sebagai berikut:

1. Pada tahap perencanaan, guru telah melakukan persiapan pembelajaran dengan matang, Kegiatan pembelajaran telah tergambar jelas pada RPP yang telah dipersiapkan. Dengan demikian, pada siklus berikutnya guru tidak akan melakukan perubahan pada UP, hanya lebih mengoptimalkan proses pernbelajaran sesuai dengan prosedur Strategi The Firing Line untuk mencapai tujuan secara maksimal. 
2. Pada kegiatan inti pelaksanaan tindakan untuk siklus kedua, guru akan menjelaskan lebih final lagi mengenai materi pelajaran. Tujuannya agar siswa memiliki pengetahuan dan pemahaman rnantap dan pada saat-saat tertentu siswa dapat mengemukakan pengetahuannya tersebut.

3. Rata-rata aktivitas guru pada siklus pertama dikategorikan cukup sempurna, oleh karena guru perlu mengadakan tindakan perbaikan dalam proses pembelajaran pada beberapa aspek terutama pada 6 aspek dari 7 aspek yang masih tergolong cukup sempuma yaitu aspek-aspek sebagai berikut : Guru menentukan tujuan yang akan disukai dengan menggunakan "garis lingkaran", seperti peserta didik dapat mengajar satu sama lain. Guru mengatur kursi-kursi dalam dua baris yang berhadapan antara X dan Y usahakan kursi-karsi itu cukup untuk semua peserta di kelas. Guru mendistribusikan kepada setiap siswa atau kelompok $X$ sebuah kartu yang berisi tugas. Guru memberikan instruksi kepada peserta kelompok Y di hadapan untuk merespon. Guru meminta kelompok $\mathrm{X}$ memulai tugas pertama. Setelah periode waktu yang singkat umumkan bahwa. waktu untuk semua peserta $\mathrm{Y}$ untuk merespon tugas kelompok $\mathrm{X}$ yang telah disampaikan. Guru memerintahkan kembali kepada teman $\mathrm{X}$ menyampaikan tugasnya kepada teman Y di hadapannya. Teruskan untuk sebanyak mungkin tugas berbeda yang kamu miliki.

4. Sedangkan untuk aktivitas belajar siswa secara klasikal berada pada kategori tinggi, akan tetapi belum mencapai persentase yang telah ditetapkan yaitu $75 \%$, sehingga pada siklus berikutnya, peneliti berusaha untuk meningkatkan aktivitas pembelajaran dengan lebih maksimal sehingga tujuan pembelajaran ataupun aktivitas belajar siswa dapat meningkat

\section{c. Siklus II}

Pada siklus II pertemuan pertama aktivitas belajar siswa dapat disimpulkan bahwa aktivitas belajar siswa pada siklus pertama secara klasikal diperoleh jumlah skor 1040 berada pada interval dengan kategori tinggi. Kemudian rata-rata klasikal aktivitas belajar siswa adalah 70,7\% tergolong cukup tinggi. Sedangkan pertemuan kedua disimpulkan bahwa aktivitas belajar siswa pada siklus kedua secara klasikal diperoleh jumlah skor 1211 berada pada interval dengan kategori sangat tinggi. Kemudian rata-rata klasikal aktivitas belajar siswa adalah 82,4 \% tergolong tinggi, dan pertemuan ketiga disimpulkan bahwa aktivitas belajar siswa pada silklus ketiga secara klasikal diperoleh jumlah skor 1298 berada pada interval dengan kategori sangat tinggi. Kemudian rata-rata klasikal aktivitas belajar siswa adalah 88,2\% tergolong tinggi.

Berdasarkan dari data perolehan observasi terhadap aktivitas belajar siswa dalam pelajaran IPS melalui penerapan Strategi The Firing Line dalam pelajaran IPS Kelas VII.2 SMPN 21 Pekanbaru secara klasikal tergolong tinggi, artinya dalam proses pembelajaran aktivitas belajar siswa telah mencapai target yang telah diharapkan yaitu sesuai dengan kriteria keberhasilan pembelajaran, yaitu 75\%. Aktivitas guru juga mengalami peningkatan, dan 7 aspek aktivitas dapat terlaksana dengan sangat sempurna. Perolehan nilai aktivitas guru dalam 7 aspek yang dijadikan penilaian didapat 6 aktivitas guru yang rnemperoleh nilai sangat sempurna, yaitu pada aspek: Guru menentukan tujuan yang akan disukai dengan menggunakan "garis lingkaran", seperti peserta didik dapat mengajar satu sama lain. Guru mengatur kursi-kursi dalam dua baris yang berhadapan antara $\mathrm{X}$ dan Y usahakan kursi-kursi itu cukup untuk semua peserta kelas. Guru memisahkan kursi-kursi itu ke dalam kelompok-kelompok tiga sampai lima pada setiap baris. Guru mendistribusikan kepada setiap siswa atau kelompok $\mathrm{X}$ sebuah kartu yang berisi tugas. Guru menginstruksikan kepada peserta kelompok Y di hadapan untuk merespon. Guru memerintahkan kembali kepada teman $\mathrm{X}$ menyampaikan tugasnya kepada teman $\mathrm{Y}$ di hadapannya Teruskan untuk sebanyak mungkin tugas berbeda yang kamu miliki.

Sedangkan aktivitas guru lainnya terlaksana, dengan sempurna. Terutama pada aspek: Guru meminta kelompok $X$ memulai tugas pertama. Setelah periode waktu yang singkat umumkan bahwa waktu untuk sernua peserta $\mathrm{Y}$ untuk merespon tugas kelompok $\mathrm{X}$ yang telah disampaikan 


\section{Pembahasan}

\section{a. Aktivitas Guru}

Dari hasil observasi pada siklus pertama yang menunjukkan bahwa aktivitas guru pada siklus I pertemuan pertama hanya mencapai skor 17 berada pada interval 12,6- 17,6 dengan kategori kurang sernpurna Sedangkan pada pertemuam kedua mencapai skor 22 berada pada interval 18,6-22,6 dengan kategoni cukup sempurna, sedangkan pada pertemuan ketiga mencapai skor 24 berada pada interval 23,6 - 28,6 dengan kategori sempurna. Kemudian hasil pengamatan aktivitas guru pada siklus II pada pertemuan pertama terjadi peningkatan dengan skor 25 berada pada interval 23,6-28,6 dengan katagori Sempurna. Sedangkan pada pertemuan kedua juga terjadi peningkatan dengan jumlah skor 32 berada pada interval 29,6-35 dengan kategori sangat sempuma, begitu juga pada pertemuan ketiga terjadi peningkatan pada setiap aktivitas guru dengan jumlah skor 34 berada pada inteval 29,6-35 dengan kategori, sangat sempurna

\section{b. Aktivitas Siswa}

Berdasarkan hasil observasi pada siklus pertama yang menunjukkan bahwa tingkat aktivitas belajar siswa sebeluan dilakukan tindakan diperoleh jumlah skor sebesar 788 dengan kategori rendah dengan rata-rata persentase 53,6. pada siklus I terjadi peningkatan yaitu mencapai sokr 960 dengan rata-rata persentase 65,3 dalarn kategori cukup tinggi, Sedangkan hasil pengamatan aktivitas belajar siswa pada siklus II juga terjadi peningkatan yaitu rnencapai skor 1296, dengan rata-rata persentase 88,2. dalam kategori tinggi.

Perbandingan antara aktivitas belajar siswa pada data awal, siklus I dan Siklus II secara jelas dapat dilihat pada Tabel berikut ini:

Tabel 2. Rekapitulasi Hasil Pengamatan Aktivitas Belajar Siswa

\begin{tabular}{|c|c|c|c|c|c|c|c|c|c|c|}
\hline \multirow{2}{*}{ No } & \multirow{2}{*}{ Siklus } & \multicolumn{7}{|c|}{ Aktivitas yang diamati } & \multirow{2}{*}{ Kkor } & \multirow{2}{*}{ Kategori } \\
\cline { 3 - 8 } & & 1 & 2 & 3 & 4 & 5 & 6 & 7 & & \\
\hline 1 & Data Awal & 111 & 112 & 107 & 114 & 100 & 120 & 124 & 788 & RENDAH \\
\hline & Persentase & 52.9 & 53.3 & 51 & 54.3 & 47.6 & 57.1 & 59 & 53.605 & Kurang tinggi \\
\hline 1 & Pertemuan 1 & 125 & 106 & 110 & 107 & 110 & 118 & 132 & 808 & RENDAH \\
\hline & Persentase & 59.5 & 50.5 & 52.4 & 51 & 52.4 & 56.2 & 62.9 & 54.966 & Kurang tinggi \\
\hline 2 & Pertemuan 2 & 135 & 127 & 123 & 117 & 122 & 139 & 142 & 905 & Cukup Tinggi \\
\hline & Persentase & 64.3 & 60.5 & 58.6 & 55.7 & 58.1 & 66.2 & 67.6 & 61.565 & Cukup Tinggi \\
\hline 3 & Pertemuan 3 & 133 & 138 & 141 & 140 & 134 & 135 & 139 & 960 & TINGGI \\
\hline & Persentase & 63.3 & 65.7 & 67.1 & 66.7 & 63.8 & 64.3 & 66.2 & 65.306 & Cukup Tinggi \\
\hline 4 & Pertemuan 4 & 154 & 147 & 146 & 152 & 143 & 145 & 153 & 1040 & TINGGI \\
\hline & Persentase & 73 & 70 & 70 & 72 & 68 & 69 & 73 & 71 & Cukup Tinggi \\
\hline 5 & Pertemuan 5 & 176 & 182 & 177 & 174 & 168 & 160 & 174 & 1211 & Tinggi \\
\hline & Persentase & 83.8 & 86.7 & 84.3 & 82.9 & 80 & 76.2 & 82.9 & 82.381 & Tinggi \\
\hline 6 & Pertemuan 6 & 184 & 180 & 193 & 189 & 183 & 181 & 186 & 1296 & Sangat Tinggi \\
\hline & Persentase & 88 & 86 & 92 & 90 & 87 & 86 & 89 & 88.2 & Sangat Tinggi \\
\hline
\end{tabular}

Selanjutnya perbandingan antara aktivitas belajar siswa pada data awal, Siklus I dan Siklus II secara jelas juga dilihat dalam diagram berikut: 


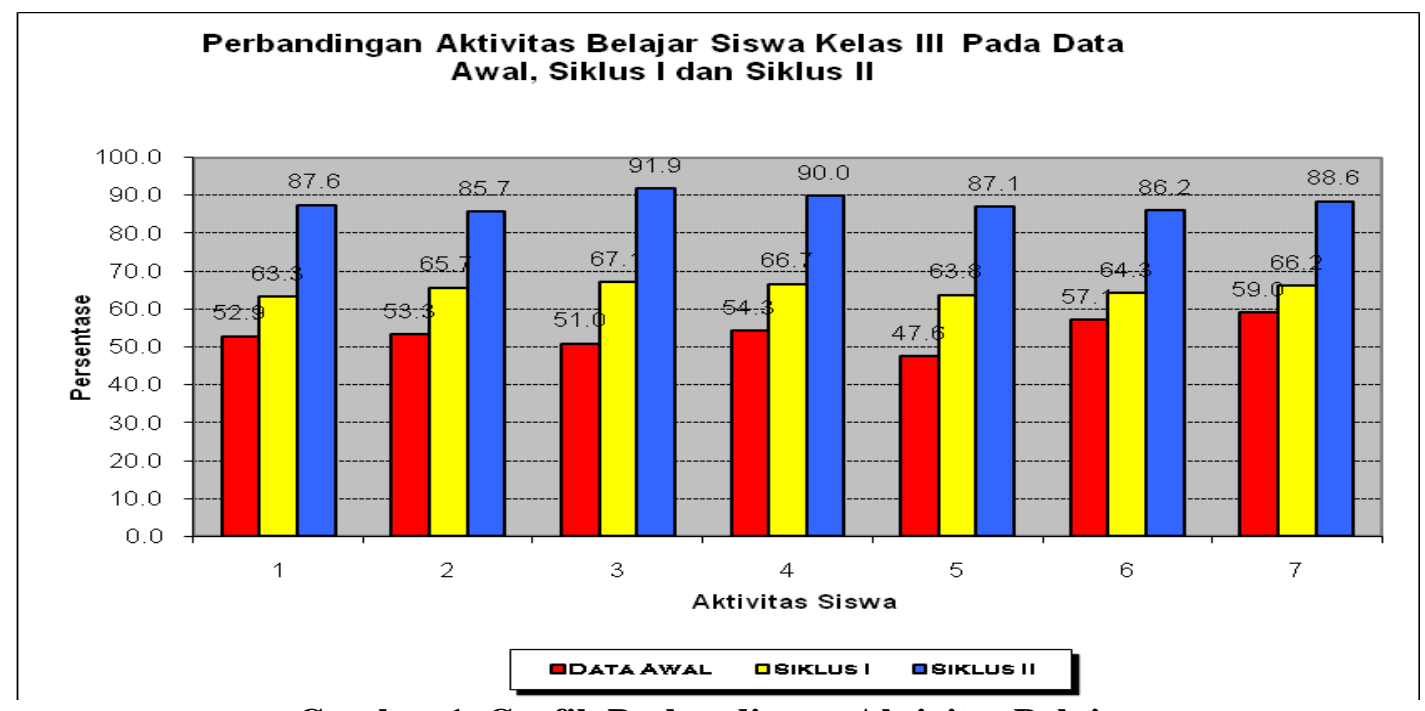

Gambar 1. Grafik Perbandingan Aktivitas Belajar

Meningkatnya aktivitas belajar siswa pada siklus II dibandingkan pada siklus I menunjukkan bahwa perbaikan pembelajaran dapat memecahkan permasalahan yang dihadapi. Artinya, perencanaan pembelajaran yang dibuat sesuai untuk mengatasi permasalahan rendahnya aktivitas belajar siswa yang terjadi di dalam kelas selama ini. lebih lanjut, adanya peningkatan aktivitas belajar siswa pada mata pelajaran IPS dan sebelumnya ke siklus I dan ke siklus II menunjukkan bahwa melalui Strategi The Firing Line dapat meningkatkan hasil belajar IPS siswa Kelas VII.2 SMPN 21 Pekanbaru.

Berdasarkan hasil penelitian dan pembahasan sebagaimana telah diuraikan di atas menjelaskan bahwa dengan penerapan Strategi The Firing Line dalam pelajaran IPS dapat meningkatkan aktivitas belajar siswa Kelas VII.2 SMPN 21 Pekanbaru ."dapat diterima".

\section{KESIMPULAN}

Berdasarkan hasil pembahasan dan analisis seperti disampaikan pada bab IV dapat disimpulkan bahwa rnelalui Strategi The Firing Line dalam proses pembelajaran IPS aktivitas belajar Kelas VII.2 SDN 003 Pagaran nTapah Darussalam dapat disimpulkan bahwa hasil pembelajaran melalui Strategi The Firing Line diketahui rata-rata keaktivan siswa menjadi lebih baik jika dibandingkan dengan sebelum diterapkannya strategi pembelajaran tersebut. Dimana sebelum diterapkannya Strategi The Firing Line, keaktivan siswa memperoleh persentase rata-rata sebesar 53,6\% siswa yang aktif. Namun setelah diterapkannya strategi tersebut, keaktivan siswa pada siklus pertama meningkat menjadi $65,3 \%$. Sedangkan pada siklus kedua, keaktivan siswa tercapai pada. rata-rata $88,2 \%$.

\section{SARAN}

Bertolak dari kesimpulan dan pembahasan hasil penelitian di atas, berkaitan dengan Strategi The Firing Line yang telah dilaksanakan, peneliti mengajukan beberapa saran, sebagai berikut:

a. Guru

Sebaiknya lebih sering menerapkannya dalam proses pembelajaran, khususnya pada pelajaran Ilmu Pengetahuan Sosial (IPS), dan guru perlu melakukan upaya-upaya guna mempertahankan hasil belajar siswa demi tercapainya hasil belajar yang optimal. 
b. Siswa

Sebaiknya sebelum melakukan pelaksanaan tindakan Strategi The Firing Line siswa terlebih dahulu membaca pelajaran yang akan dipelajari.

c. Kepala sekolah

Seharusnya selalu memberikan masukan kepada guru yang mengajar untuk melakukan upaya-upaya guna mempertahankan hasil belajar siswa demi tercapainya hasil belajar yang optimal.

d. Sekolah

Untuk dapat menyiapkan perlengkapan-perlengkapan yang diperlukan dalam menerapkan Strategi The Firing Line untuk meningkatkan hasil belajar siswa.

\section{DAFTAR PUSTAKA}

[1] Depdiknas. Standar Komptensi dan Komptensi Dasar Tingkat SD/MI, Depdiknas, Jakarta, 2006.

[2] Djamarah, Syaiful Bahri. 2002. Strategi Belajar Mengajar. Jakarta. Rineka Cipta.

[3] Masnur Musllich, KTSP Pembelajaran Berbasis Kompetensi dan Kontektual. Jakarta: Bumi Aksara. 2007.

[4] Muhibbin Syah. 2006. Psikologi Belajar. Jakarta: Rajawali Press

[5] Oemar Hamalik, Pendekatan Baru Strategi Belajar Mengajar Berdasarkan CBSA, Banding: Sinar Baru Algansindo, 2009.

[6] Silbermen, Aktive Learning 101 Straretegi Pembelajaran Aktif, Yogyakarta: Yappendis, 2002. 